\title{
Recent Advances in Enhancing the Productivity of Mango (Mangifera indica L.) through Hi-tech Practices
}

\author{
S. Parthiban ${ }^{1}$, V. P. Santhi ${ }^{1 *}$, M. S. Snehapriya ${ }^{2}$, K. Indumathi ${ }^{1}$ and P. Masilamani ${ }^{3}$ \\ ${ }^{1}$ Department of Fruit Science, Horticultural College and Research Institute for Women, Tamil \\ Nadu Agricultural University, Navalur Kuttapattu, Trichy- 620 027, India \\ ${ }^{2}$ Department of Fruit Science, Sri Konda Laxman Telangana State Horticultural University, \\ Hyderabad, Telangana-500030, India \\ ${ }^{3}$ Anbil Dharmalingam Agricultural College and Research Institute, Tamil Nadu Agricultural \\ University, Trichy -620 027, Tamil Nadu, India \\ *Corresponding author
}

\section{A B S T R A C T}

K e y w o r d s
$\begin{aligned} & \text { Hi-tech practices, } \\ & \text { High density } \\ & \text { planting, Ultra high } \\ & \text { density planting } \\ & \text { productivity, } \\ & \text { Growth regulator }\end{aligned}$
Article Info
$\begin{aligned} & \text { Accepted: } \\ & 18 \text { July } 2020 \\ & \text { Available Online: } \\ & 10 \text { August } 2020\end{aligned}$

\section{Introduction}

Globally, India is the second largest producer of fruits followed by China. India is a vast country blessed with varied climatic conditions favouring cultivation of a vast range of fruit crops from arid, semi-arid, tropical, sub-tropical and temperate region. Horticulture production in India increased

substantially in recent years due to adoption
Food and nutritional security are emerging as the greatest challenge of the $21^{\text {st }}$ century. The pace at which population is growing it is estimated that the food demand will be doubled by 2050. The need of hour is sustainable secure and affordable way to feed the entire population with nutritious food. Hence it is essential to incorporate high tech practices in our day to day cultivation practices to increase both quantity as well as quality of the produce. Even though, India ranks first in production of mango, it is far behind in terms of productivity. There is a great scope for increasing the productivity. In this review we have discussed a few important hi - tech practices in the fruit crop mango. The novel techniques that cab be adopted to improve the mango productivity are High Density Planting, fertigation technology under UHDP, mulching, canopy management, using of growth regulators, floral manipulation by application of exogenous plant hormones, induction of off - season flowering, ethylene spray, paclobutrazol and top working of old and senile orchards for rejuvenation. When all these techniques are integrated and practiced, there will be remarkable increase in productivity of mango. of advanced technologies by the farmers. Over the last decade, the area under horticulture grew only by $2.6 \%$ per annum and annual production increased by $6 \%$. During 2018-2019, production of horticultural crops enhances to 314.67 Million MT of horticultural produce from an area of merely 25.87 Million Hectares surpassing the agricultural production of 285.21 Million MT from an area of 95.45 Million Hectares 
(Indian Hort. Database, 2018-19. The production of fruits has increased from 50.9 MT to 96.75 MT since 2004-05 to 2018-19. One of the important fruit crop in which India is leading in production is Mango.

Mango is a tropical as well as subtropical plant that grows almost in all the states of India. It is one of the venerable fruits of India. It is also considered as the National fruit of India. Mango deserves to be 'King of fruits' due to its incomparable taste and nutritional value. It is the most popular and favourite fruit all over India.

Mango (Mangifera indica L.) is grown in more than 1000 countries now. It is one of the most important fruit crops of tropical and subtropical regions. Mango always at its peak in area, production, nutritive value and popularity of appeal and other fruits can't compete with it (Ranjith Singh and Saxena, 2005).

The moisture content of ripe mangoes is 73.00- $86.70 \%$, carbohydrate $11.60-24.30 \%$, protein $0.50-1.00 \%$, fibre $1.10 \%$, TSS $12.00-23.00^{\circ} \mathrm{B}$, acidity $0.12-0.38 \%$, vitamin A $6375-20750 \mu \mathrm{g} / 100 \mathrm{~g}$, vitamin $\mathrm{B}_{1} 40.00$ $\mathrm{mg} / 100 \mathrm{~g}$ and ascorbic acid $0.46 \mathrm{mg} / 100 \mathrm{~g}$ (Bose, 2001).

India produces about 50 per cent of world mango production with largest area (Galan Sauco, 2013). In India, mango is cultivated in more than 40 per cent of total fruit area. The area occupied by Mango in India is 22.58 lakh hectare, where the annual production and productivity is 218.22 lakh MT and 9.7 MT/ ha respectively as against a higher productivity of $30 \mathrm{MT} /$ ha in Israel. Andhra Pradesh leads in area of mango cultivation occupying 3.63 lakh hectare followed by Uttar Pradesh occupying 2.65 lakh hectare whereas Uttar Pradesh leads in production of 45.51 lakh MT followed by Andhra Pradesh producing 43.73 lakh MT and Rajasthan leads in productivity of $17.58 \mathrm{MT} /$ ha followed by Punjab of 16.9 MT/ ha (NHB, 2017-18).

Due to tremendous increase in population and increased demand it is essential to improve the production with the available resources. The main reason for low productivity of mango in India can be attributed due to poor orchard management, dense canopies with wider spacing, poor sunlight interception and ventilation encouraging more pest and disease incidence (Kumar, 2017).

The increased productivity due to increased population can be achieved through hi-tech cultural practices such as High Density Planting, fertigation technology under UHDP, mulching, canopy management, using of growth regulators, floral manipulation in mango by application of exogenous plant hormones, induction of off - season flowering, ethylene spray, paclobutrazol application and top working of old and senile orchards for rejuvenation by reducing long gestation period, reduced pest and diseases incidence and hence increase in yield per unit area. In this review, we have discussed the recent hi-tech practices which have positive impact on the productivity of mango.

\section{High Density Planting}

In recent times high density planting technique in mango, have gained momentum throughout the World due to advantages of more population per unit area, early income, reduction in maintenance cost and achieving the break-even much earlier compare to traditional method of cultivation (Oosthuyse, 2009; Ram et al., 2001).

A field trial conducted on the incidence of anthracnose disease at Tamil Nadu Agricultural University indicated that the severity of the anthrocnose were more 
pronounced in the mango planted in the "Double hedge row system of planting" (Balasubramanyan et al., 2009). Under double hedge system $(5 \mathrm{~m} \times 5 \mathrm{~m}$ in one hedge row and $10 \mathrm{~m}$ between two hedges ( 435 plants $/ \mathrm{ha}$ ) of mango var. Neelum, the highest number of fruit / tree (332.6) and fruit yield $(70.6 \mathrm{~kg}$ /tree) recorded during two seasons viz., September and August,2000 compare to other planting system followed (Anbu et al.,2001c).

In mango orchards, the fruit yield reaching around $20 \mathrm{MT} /$ ha / year in the third harvest (Oosthuyse, 2009). This yield is almost three times more than the average mean yield of mango in the World by using double hedge row system of planting (Nath et al, 2007).

Gaikwad et al., (2017) followed, IPM, Global-GAP and standardized a package of practices for mango cultivars, under high density $(4.5 \mathrm{~m} \mathrm{X} 4.5 \mathrm{~m})$ and ultra- high density mango (3 m X $2 \mathrm{~m}$ ) (Fig. 2). The 'composite mango production technology' thus developed over a period of 14 years in the Research, Development and Demonstration Farms of Jain Irrigation System Limited is now extended to many growers in the country.

The gestation period for the first harvest was reduced to three to four years, yield increased two to three times and the quality of fruits was good for export and fruiting was regular even in shy-bearing cultivars like Alphonso and Himampasand (Chaudhari et al., 2019) (Fig. 1).

\section{Fertigation technology under UHDP}

Of late, high density planting (HDP) with fertigation system, has come into vogue, which is capable of removing the limitations of mango productivity in the India. Intake of potassium is very important and plays a crucial role in each and every stage of growth in mango and the rate of absorption of the potassium increased in all the stages of growth due to the application of 125 per cent RDF through drip fertigation (Srinivas, 2006).

The overall performance of five cultivars showed that even the shy, alternate bearing varieties viz., Alphonso and Himampasand, bear regular crops under UHDP, responding to pruning and Paclobutrazol treatments. Regular bearing cultivars viz., Banganapalli, Totapuri, and Ratna have recorded high yields of 20-25 t/ha indicating further scope of improvement in performance in the coming years, as these plants are only 9-12 years old. Merely following high density planting in mango will not produce expected results. Provided introduction of new and high yielding varieties, adoption of precision farming system and good managerial governance to produce excellent results. The orchard operations like pruning, spraying and harvesting are easy and more efficient (Chaudhari et al., 2019).

\section{Micronutrient deficiency}

Micronutrients deficiency in Indian soils are higher in case of Zinc (Zn) and Boron (B). It is estimated the average deficiency of $\mathrm{Zn}$ is to be around 50 now and by 2025 projected to increase $63 \%$ (Singh, 2001; Anonymous 2004). It reflects on health at risk across the globe (Alloway, 2007, Black et al., 2000)'

Application of $100 \mathrm{~g}$ borax per plant with spraying of $0.5 \%$ boric acid during the month of September- October solution at peanut and marble size of fruits useful for optimum improvement in fruit quality.

Deficiency of $\mathrm{Zn}$ ranged between 5.9 to 75.0 percent in soil and 33.3 to 100 percent in leaf tissue analysis in Uttar Pradesh (Kumar et al., 2015). The responsible factors are coarse texture of soils, low organic matter content, 
microbial activity and non-application of micronutrients in the orchards under subtropical condition. In India, $0.5 \% \mathrm{ZnSO} 4$ recommended to correct the deficiency. It is observed that enhancement of boron accumulation in the lower level concentration $\mathrm{Zn}$. But in High pH soils spraying of $0.5 \%$ boric acid causing toxicity (Adak et. al.2017). Mango cultivar Mallika found most efficient in zinc uptake when compared to Totapuri, Neelum and Alphonso (Muthaia, 2019).

\section{Expert system software}

Expert system software developed by Verma et al, 2018 on nutrients disorder/deficiency in mango for diagnosis of five major mango nutrient disorders viz., Potassium, Boron, $\mathrm{Cu}$, $\mathrm{Zn}$ and $\mathrm{Mn}$. The software advises suitable management options after diagnosis for management of identified disorder/ deficiency. It helps in taking right decision and effective in empower orchardist in knowledge dissemination.

\section{Mulching}

Plants spaced at $5.0 \times 2.5 \mathrm{~m}$ spacing with straw mulch showed the maximum plant girth whereas, plastic mulch recorded the maximum plant spread North- South direction in the same spacing. It may be attributed to the synergistic and interactive influence of spacing and black polyethylene mulch on the creation of a comparatively favourable environment (microclimate) and better moisture conservation, suppression of weed growth, etc., which might have resulted in comparatively better growth of plants than other combinations in conformity with Sharma and Singh (2006).

The water vapour that evaporate from the soil surface further trapped in the plastic and dropped again into the upper soil surface which increases soil moisture content in the root zone. Temperature and soil moisture regimes can be improved by using proper mulching material tropical fruits (Dutta and Majumder (2009). Shirgure (2012) reported the highest increase in plant height with black polyethylene mulch. This is in conformity with Ghosh and Bauri (2003) in mango cv. Himsagar.

The main benefit of mulching is to raise the soil temperature in planted zone, which promotes crop yield (Panwar et al., 2007). Increased macronutrient uptake with the use of mulching was also reported in mango (Dutta and Kundu, 2009).

Among the various mulching materials used, the black plastic mulch with a thickness of $100 \mu$ produced a good nutrient status in the soil and plant and also, enhanced flowering and yield when it was done during the month of October - November in the mango var. Chausa at CISH, Lucknow. Mulching was done during flower-bud differentiation (October-November) stage. The mulch encourage the lateral root growth in nutrient rich upper soil layer. But, no difference observed in dry weight of roots. The data on nutritional status revealed the improvement in levels of $\mathrm{Ca}$ in soil which is mulched (521.05 ppm), Zn (0.93 ppm), Cu (1.61 ppm), Mn $(6.66 \mathrm{ppm})$ and $\mathrm{Fe}$ (4.90 ppm) when compared to unmulched $(440.95,0.75,0.66$, 4.52 and $3.6 \mathrm{ppm}$, respectively). Among different nutrients, phosphorus $(0.21 \%)$ and potash $(0.8 \%)$ were found significantly higher in leaves of mulched plants in comparison to control (0.15 and $0.56 \%)$. Flowering and yield increase (38-70 and 40-60\%) were also recorded under mulch in 'off' and 'on' year. Among the various mulches tried, black polythene sheets decreased physiological loss in weight and increased quality parameters like improved TSS, reduction in acidity and total sugar in the cultivar Amrapalli (Bhusan and Panda 2015). These results are similar to 
the findings of Kaushik and Pallab (2018).

\section{Canopy management}

At present, India is the number one country in mango production. But the productivity is very poor ( $7.3 \mathrm{MT} / \mathrm{ha})$ when compared other mango producing countries due to use of poor planting material, traditional method of planting system, lack of awareness in training and pruning system, cultivation of alternate bearing varieties and poor orchard management (Balamohan and Gopu, 2014).

Yeshitela et al., (2003) reveals that pruning at the point of apical bud attachment induced reflowering, more rapid fruit development and more fruits per panicle. Treatments such as pruning that manipulate timing of flush development and synchronize canopy flushing have been successful in increasing flowering intensity (Yeshitela et al., 2005).

Annual tip pruning in mango resulted in synchronised and regular flowering in each year Davenport (2006). To induce uniform flowering mango var. 'Alphonso' tip pruning at $2.5 \mathrm{~cm}$ below terminal portion resulted in a regulation of vegetative growth and resulted in regular flowering in mango cv. Alphonso (Waghmare and Joshig, 2008).

Canopy management in mango cv. Alphonso under UHDP maximized the yield and maintained the optimum canopy size without overlapping (Fig.3).

\section{Treatment details}

T1- Tipping of previous season's growth T2- Light pruning: Retention of $70 \mathrm{~cm}$ from the base of the past season's growth T3- Moderate pruning: Retention of $60 \mathrm{~cm}$ from the base of the past season's growth T4- Heavy pruning: Retention of $50 \mathrm{~cm}$ from the base of the past season's growth T5- Severe pruning: 50 per cent removal of past season's growth and tipping T6- Very severe pruning: Total removal of past season's growth

Dashehari mango produced the maximum number of panicles in July pruned trees (Swaroop et al., 2010). Spraying with 100 ppm of GA3 with moderate pruning in mango increased the length of new flushes, panicle length and improved yield of mango var. Zebda in the off-year season (Shaban, 2009).

For achieving higher productivity in mango, High-Density Planting (HDP) system should be followed with drip fertigation system coupled with proper canopy management practices (Kumar, 2013; Kumar, 2019). Canopy management practice alone will not be sufficient to tap its potential towards increasing productivity. Hence all other feasible technologies capable of input optimisation and increasing productivity have to be followed simultaneously.

\section{Growth regulators}

Mango is beset with several problems like erratic flowering, malformation, low production of perfect flowers, poor fruit set, heavy fruit drop, and severe incidence of pests, diseases and disorders which directly and indirectly affect the production and cause much economic loss to the grower. Under these conditions, it was conceived to take the help of plant hormones to solve the above problems.

Plant growth regulators are being tested for successful enhancement and /or regulation of vegetative growth, correction of erratic flowering, enhancement of flowering, perfect flowers and fruit set and reduction of fruit shedding and finally enhancing yield and fruit quality.

Cycocel (Chloremquat, CCC) sprayed at 
1000-4000ppm on panicles was the best one in enhancing fruit set, followed by $\mathrm{MH}$ at $1500 \mathrm{ppm}$ in mango at Navasari, Gujarat (Chaudhuri et al., 2014).

At harvest, fruit number was higher under NAA (20ppm) treatment in 'Alphonso' at Bangalore (Upreti et al., 2011). Application of NAA (50ppm) significantly improved fruit retention, yield and fruit quality of 'Amrapali' mango fruits in West Bengal (Animesh and Ghosh, 2011). Improvement of fruit retention due to $\mathrm{GA}_{3}$ application at post-bloom stage was reported (Srilatha, 2003). $\mathrm{GA}_{3}$ at 30ppm recorded higher fruit retention and yield per plant in mango (Sarkar and Ghosh, 2004).

Application of PGR showed some benefits on quality of fruits.

Post harvest application of $\mathrm{GA}_{3}$ to delay ripening of 'Lucknow' mangoes retarded the increase in TSS, total sugars, loss of ascorbic acid content and acidity and reduced spoilage of fruits (Jain and Mukherjee, 2001).

1-MCP positively affected the quality of 'Palmer' fruits and treatment with 1-MCP at $150 \mathrm{ppm}$ contributed to a reduction in fruit softening unlike the 18 days of refrigeration storage at room temperature (Hojo et al., 2006). 1-MCP plus controlled atmosphere reduced the incidence of anthracnose, weight and firmness loss, delayed skin and flesh colour development, prevented the increase in soluble solids concentration / titrable acid ratio, ethanol and acetaldehyde content, maintained the ascorbic acid, carotenoid, total phenol and flavonoid content and antioxidant scavenging activity in hot water treated 'Kent' mangoes (Devender et al., 2012).

Several investigators reported the improvement of fruit quality of mango with the application of Paclobutrazol (PBZ). In mango, cv. 'Neelum', tree sprayed with $2 \%$
KNO3 (Vijayalakshmi and Srinivasan, 2000; Nandkumar and Kurupaiah, 2006; Chusri et al., 2008, Bamini et al., 2009 and Sarkar and Rahim, 2012).

Higher doses of PBZ resulted in higher content of TSS, less total acidity, less firmness and greatest weight loss in Mexico (Robellede - Martinez et al., 2008). Physiological loss in weight was lowest in PBZ treated trees of 'Neelum' at Periyakulam in Tamilnadu (Bamini et al., 2009). PBZ at 750 ppm during mid-October recorded heaviest fruits, highest edible portion, lowest stone to pulp and peel to pulp ratio in mango, besides overall improvement in fruit quality in Bangladesh (Sarkar and Rahim, 2012).

The productivity of mango in India is very low compared to its potential as well as to some mango growing countries like Brazil, Israel, Australia etc. The low productivity in mango is attributed to several factors like genetically, excessive vegetative growth, irregularity in bearing, less proportion of hermaphrodite flowers, inadequate fruit set followed by heavy fruit drop, incidence of pests and diseases etc. Besides nutrients, phytohormones also play role in fruit production of mango.

The increase in fruit retention and yield was ascribed to NAA which caused cell elongation by enlargement of vacuoles in the cells and loosening of cell walls (Agrawal and Dikshit, 2008, Vejendla et al., 2008).

Foliar sprays of CCC (3500 ppm) given prior to fruit bud differentiation increased the number of fruits and yield per tree in 'Kesar' cultivar at Navasari (Chaudhuri et al., 2014, Dalal et al., 2005).

Several studies over the world with PBZ on mango resulted in higher yields (Notodimedjo, 2000; Anbu et al., 2001a; 
Honda et al., 2001; Singh and Saini, 2001; Yeshitela et al., 2004, Baghel et al., 2004, Karuna et al., 2005; 2007; Yadav et al., 2005; Singh and Singh, 2006 Balasubramanyam et al., 2006; Rajkumar et al., 2007b; Karuna and Mankar, 2008; Vejendla et al., 2008; Reddy and Kurian, 2008; Martinez et al., 2008; Bamini et al., 2009; Singh et al., 2010; Muhammad et al., 2010; Nafeez et al., 2010; Tandel and Patel, 2011; Chaudhuri et al., 2014; Sarkar and Rahim, 2012; Kotur, 2012; Husen et al., 2012; Bhagwan et al., 2013; Upreti et al., 2013; Satyendra Singh et al., 2014; Srilatha et al., 2015) PBZ also increased yield both in 'on' and 'off' years particularly in 'on' year in mango (Karuna et al., 2007). Application of PBZ to rejuvenated mango trees enhanced early panicle emergence and also enabled the trees to produce shorter and compact panicles with more number of hermaphrodite flowers, which resulted in more fruit set and more fruit yield per tree in cv. Neelum at Periyakulam, Tamil Nadu, India (Bamini et al., 2009). Further, PBZ reduced the incidence of malformation, leading to increased yield in Pakistan (Muhammad et al., 2010; Nafeez et al., 2010). GA bio synthesis inhibitors such as paclobutrazol hasten and increase the flowering intensity of mango (Blaikieet et al., 2004, Abdel Rahim, et al., 2011, Gopu and Balamohan,2015) also reduce the vegetative vigour. The application of paclobutrazol followed by application of a dormancybreaking substances has forced mango to produce off- season flowers.

Increased fruit yields due to soil application of PBZ has been attributed to inhibition of gibberellin synthesis in treated plants, which changes the sink source relationship in favour of fruit production by reallocating the accumulated carbohydrate sources towards flowering and fruiting (Karuna et al., 2007; Sarkar and Rahim, 2002). Inhibition of gibberellin synthesis checks the vegetative growth by which food and energy are saved and food particularly carbohydrates is accumulated in the plant (Baghel et al., 2004; Rajkumar et al., 2007b; Satyendra Singh, et $a l ., 2014)$. Increase in the number of panicles and perfect flowers higher fruit set and fruit retention, ultimately increase in yield (Singh et al., 2010).

PBZ application is beneficial under stress conditions as PBZ alter the equilibrium between free radical production and enzymatic defence reaction by enhancing the proline content and free radical scavenging capacity (Srivastava et al., 2010).

In mango, higher production of total sugars. Reducing sugar and $\mathrm{C}: \mathrm{N}$ ratio in paclobutrazol treated trees were observed (Upreti et al., 2014). Starch is one of the basic reserves of carbohydrates and its direct role in flower induction of mango (Fig.4).

In the Philippines, foliar spray of ethylene (Ethephon) at a concentration of 125- 200 ppm resulted in flowering of mango $\mathrm{cv}$. karabavo within six weeks after treatment. Paclobutrazol application increases the percentage of flowering and also improves the fruit retention capacity of the trees (Vijaykrishna et al., 2016).

In mango cv. Neelum, trees sprayed with $2 \%$ $\mathrm{KNO}_{3}$ at mustard size resulted in maximum yield of $17.67 \mathrm{~kg}$ (111.7 fruits) per tree during offseason (Anbu, et al., 2001b). Foliar application of $\mathrm{KNO}_{3}$ during warm temperature condition resulted in bud break in about four weeks time (Davenport, 2003). Early and profuse vegetative growth, early flowering and increase in yield were observed by the foliar application of $\mathrm{KNO}_{3}, \mathrm{NH}_{4} \mathrm{NO}_{3}$ (Patil et al., 2013). Spraying of 4\% KNO3 observed increased flowering and fruiting in the varieties of 'Apple' and 'Ngowe' mango (Maloba et al., 2017). 
Table.1 Fertigation technology under HDP

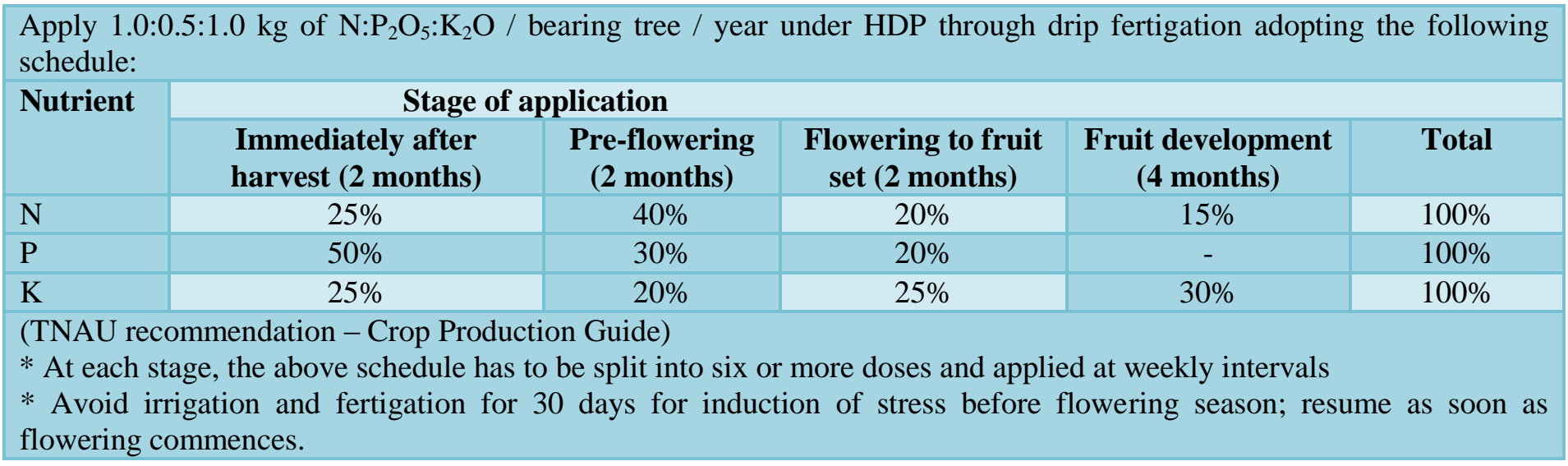

Table.2 Fertilizer doses for UHDP mango

\begin{tabular}{|l|c|c|c|c|}
\hline \multirow{2}{*}{ Age of the tree } & \multicolumn{3}{|c|}{ Fertilizer (g/tree/year) } & \multirow{2}{*}{ FYM (kg/tree/year) } \\
\cline { 2 - 4 } & $\mathrm{N}$ & $\mathrm{P}_{2} \mathrm{O}_{5}$ & $\mathrm{~K}_{2} \mathrm{O}$ & \\
\hline 1st year & 35 & 15 & 25 & 5 \\
\hline 2nd year & 45 & 25 & 50 & 5 \\
\hline 3rd year & 75 & 50 & 75 & 10 \\
\hline 4th year onwards & 120 & 75 & 100 & 15 \\
\hline
\end{tabular}

Table.3 Application scheduling for bearing mango orchard

\begin{tabular}{|l|c|c|c|c|c|}
\hline \multirow{2}{*}{ Nutrient } & \multicolumn{4}{|c|}{ Stages of application } & Total \\
\cline { 2 - 5 } & $\begin{array}{c}\text { Immediately } \\
\text { After pruning }\end{array}$ & $\begin{array}{c}\text { Pre } \\
\text { flowering }\end{array}$ & $\begin{array}{c}\text { Flowering to } \\
\text { fruit set }\end{array}$ & $\begin{array}{c}\text { Fruit } \\
\text { development }\end{array}$ & \\
\hline N & $25 \%$ & $40 \%$ & $20 \%$ & $15 \%$ & $100 \%$ \\
\hline P2O5 & $40 \%$ & $30 \%$ & $20 \%$ & $10 \%$ & $100 \%$ \\
\hline K2O & $25 \%$ & $20 \%$ & $20 \%$ & $35 \%$ & $100 \%$ \\
\hline
\end{tabular}

Table.4 Fertigation schedule and quantity (kg//ha)

\begin{tabular}{|c|c|c|c|c|c|c|}
\hline Year & Months & Number of Doses & Urea & $\mathrm{H}_{3} \mathrm{PO}_{4}$ & MOP & $\mathrm{MgSO}_{4}$ \\
\hline \multirow[t]{2}{*}{$1^{\text {st }}$ Year } & July-Sept. & 12 & 3.5 & 1.3 & 2 & 0 \\
\hline & Jan- May & 20 & 4.2 & 1.5 & 2.3 & 0 \\
\hline \multirow[t]{2}{*}{$2^{\text {nd }}$ Year } & July- Sept. & 12 & 6.8 & 3 & 5.8 & 0.695 \\
\hline & Jan - May & 20 & 4 & 1.8 & 3.5 & 0.418 \\
\hline \multirow[t]{3}{*}{$3^{\text {rd }}$ Year } & 15 June- Aug & 12 & 11.3 & 5.8 & 8.8 & 1.4 \\
\hline & September & 4 & 3.5 & 3 & 7.8 & 0 \\
\hline & Jan-May & 20 & 8 & 3 & 3.8 & 0.832 \\
\hline \multirow{3}{*}{$\begin{array}{l}4^{\text {th }} \text { Year } \\
\text { onwards }\end{array}$} & 15 June- Aug & 12 & 18 & 8.8 & 11.5 & 2.08 \\
\hline & September & 4 & 5.5 & 4.3 & 10.5 & 0 \\
\hline & Jan- March & 12 & 12.8 & 4.3 & 8 & 2.08 \\
\hline
\end{tabular}

Source: Chaudhari et al., 2019 
Fig.1 Effect of plant spacing on yield of mango cv. Kesar

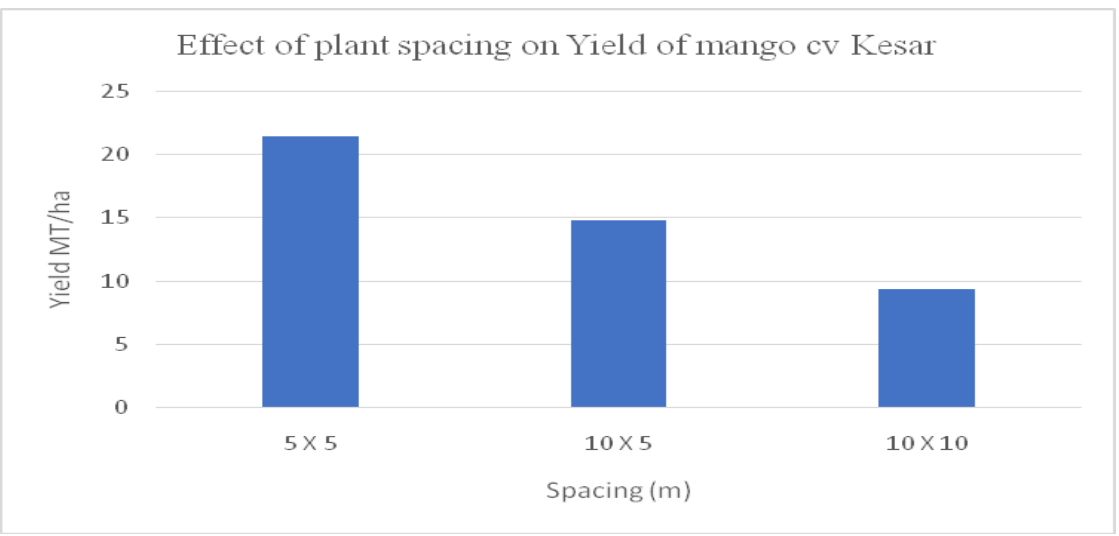

Source: Gaikwad et al., 2017

Fig.2 High Density planting mango (3 m X 2 m)

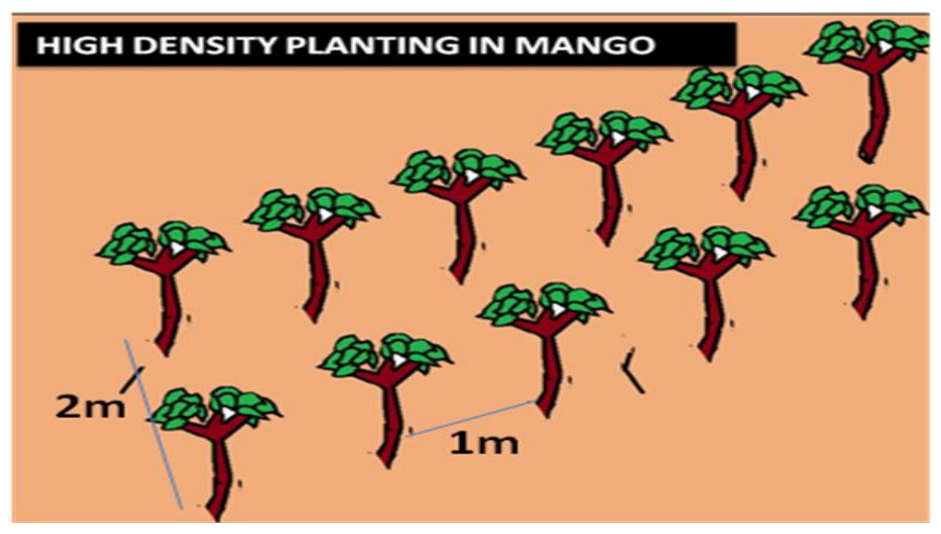

Fig.3 Effect of pruning on number of fruits per tree and yield per tree $(\mathrm{kg})$ in mango cv. Alphonso

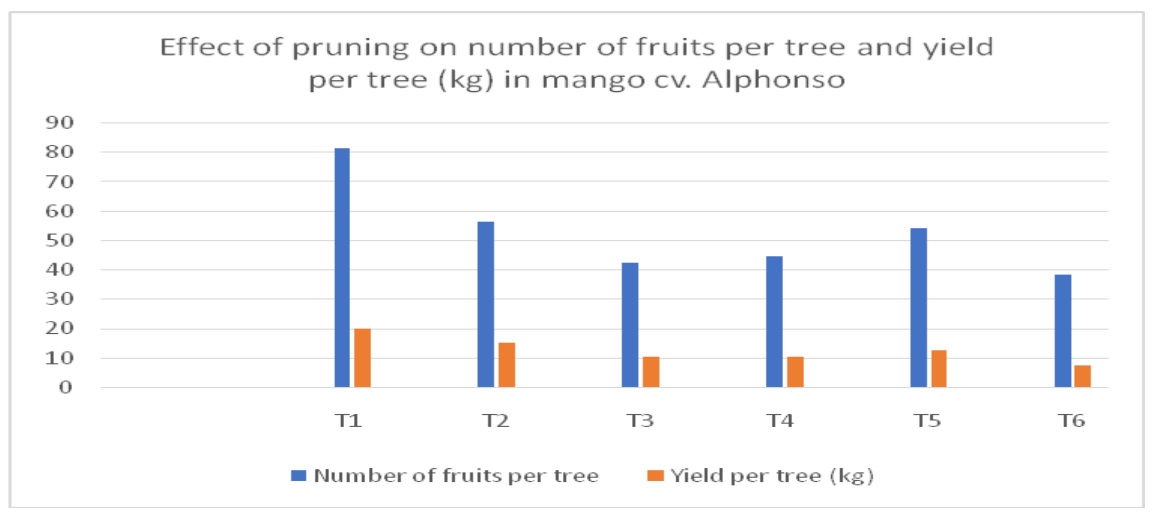

(Gopu et al., 2014) 
Fig.4 Induction of off season flowering in mango
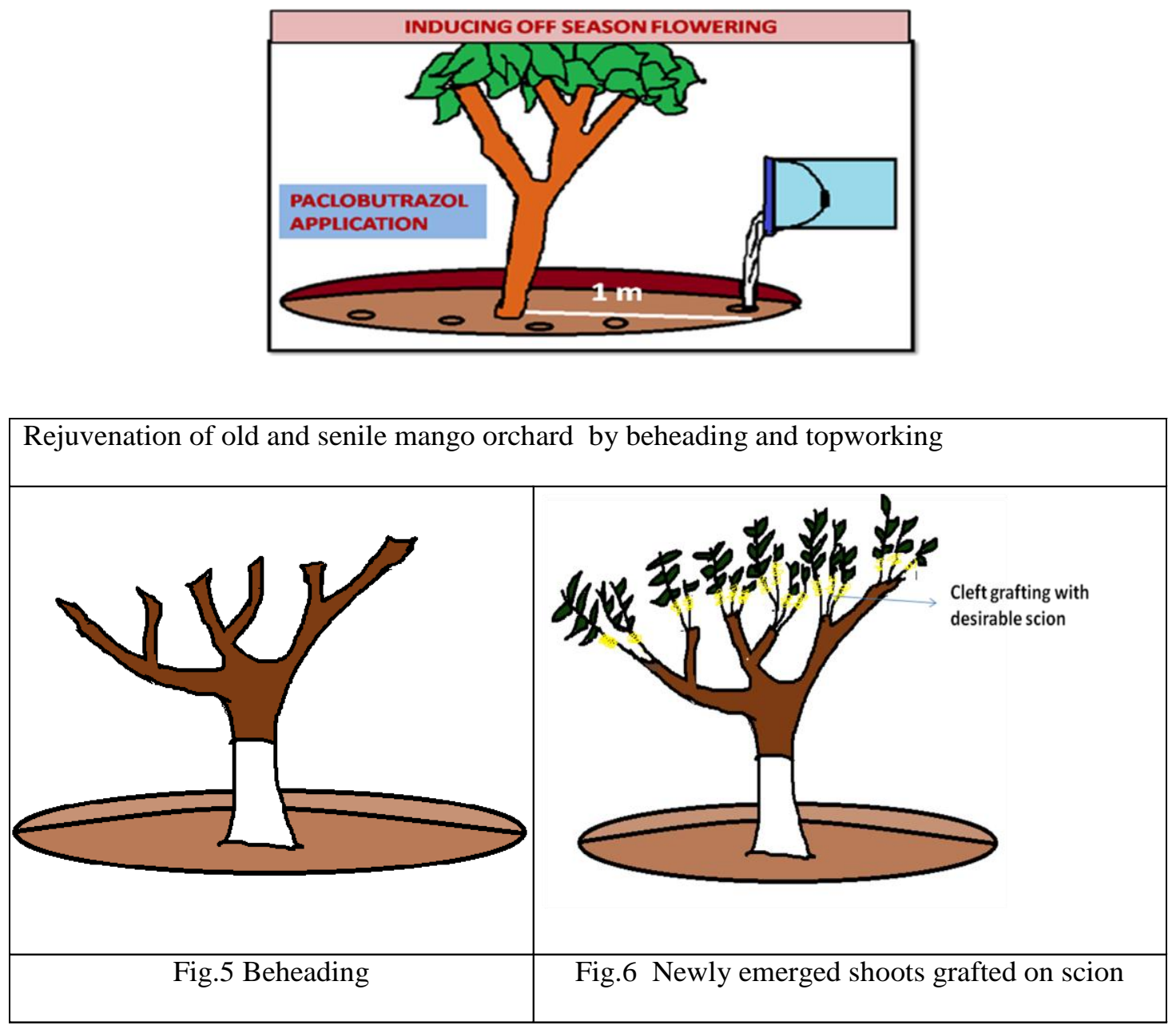

Flowering mechanism in mango is not controlled by a single factor due to many factors like environmental influence, plant growth regulators and other interactions with vegetative growth pattern. It is also apparent that rarely can one factor be considered in isolation. High level of starch, some auxinlike regulators and inhibitors and a low level of gibberellins may be seemed favourable for flowering in shoots. For increasing sustainable yield in mango, crop regulation is necessary. Use of plant growth regulator (Paclobutrazol), shoot pruning, use of fruit set chemicals and regulation of flower drop are found to be the most promising approaches for ensuring flowering and enhancing fruit yield under commercial cultivation (Usha, 2018). Mango production is seasonal which leads glut in the market therefore, fetches poor prices and sometime also leads higher fruit spoilage too. This seasonal supply is also limited to few days to few months. In this case, paclobutrazol can be commercially used for regulating the crop.

Top working of senile orchards for rejuvenation

Choice varieties like Alphonso and Banganapalli are recommended for use as 
scions for top working. For getting proper results, the mango trees are to be cut $2-3 \mathrm{~m}$ above the ground depending on the framework of the tree during the month of July-August. Cleft method of grafting or softwood grafting was done on the emerging shoots on the main stem from the cut end during September- October (Vinod et al., 2017) (Fig.5 and fig.6). Yield reduction in old and senile orchards observed due to age of the tree, poor canopy management and incompatible varieties (Jahangeer et al., 2011). Pruning as facilitating light penetration, young shoots and canopy management might lead to increased yield in old and senile orchard in mango. The maximum fruit yield $(286.7 \mathrm{~kg} / \mathrm{tree})$ was noted in mango var. Banarasi, Langra variety after six years of pruning in 60 yrs old mango orchard was reported by Rawat and Yogesh, 2018.

In conclusion: over all, the above-mentioned novel techniques for mango are scientifically proven that they are highly potential enough to improve the crop productivity. Our ultimate aim in crop production is to increase the production by increasing the productivity with the effective utilization of optimum inputs. All these studies show that productivity of the mango crop can be increased by increasing the population per unit area. It is certain that the increased population will not perform well unless their stature maintained according to the space allotted to each of them. Here comes the relevance of canopy management. Even though we maintain number of plants with well-developed frame work, they may starve for nutrients due to competition.

This can be overcome by following the nutrient recommendation standardized for particular planting density. The method of application of all essential inputs viz., growth regulators, and micro nutrients for plant growth also has influence on crop growth and productivity. For instance, using drip system for irrigation and fertigation ensure effective uptake of water and nutrients by the plants. Hence it is clear that, besides the canopy management which includes the formative pruning and consecutive pruning after every harvest in High density planting systems, the mandatory techniques of fertigation, mulching and the use of growth regulators to promote offseason flowering and top working for rejuvenation of old orchards will ensure higher productivity in mango. Therefore, the technologies capable of improving plant growth via different cultural practices have to be utilized in an integrated manner for getting remarkable results. So, it is our duty to popularize and handover these techniques to farmers so that our ultimate goal can be achieved practically.

\section{References}

Anonymous (2004), Predominant micronutrient disorders of mango in $\mathrm{T}$. Nadu, Karnataka. Annual report of IIHR, Bangalore. P 124-28, 2004

Abdel Rahim, A.O.S., Elamin, O.M. and Bangerth, F.K.2011, Effect of paclobutrazol (pbz) on floral induction and associated hormonal and metabolic changes biennially bearing mango (Magifera indica L.). cultivars during off year. J. Agric. Biol. Sci.,6 92): 55 67.

Adak*, Kailash Kumar and Vinod Kumar Singh. (2017). Micronutrient management for mango and guava orchards: farmers' perspective. Tropical Plant Research. 4(1): 180-182. DOI: 10.22271/tpr.2017.v4.i1.026

Alloway BJ (2008) Zinc in Soils and Crop Nutrition, 2nd edition. IZA and IFA Brussels, Belgium and Paris, France, $135 \mathrm{p}$.

Anbu, S., Parthiban, J. Suresh, J. and Thangaraj, T. 2001b. High density 
planting in Mango (Mangifera indica L.). South Indian Horticulture, 49(special): 384-385.

Anbu, S., Parthiban, S, Rajanagam, J. and Thangaraj, T. 2001a. Induction of off season flowering in mango (Mangifera indica L.) using of paclobutrazol. South Indian Horticulture, 49(special): 384385.

Anbu, S., Parthiban, K. Balakrishnan, J. and Thangaraj, T. 2001b. Induction of off season flowering in mango (Mangifera indica L.). South Indian Horticulture, 49 (special): 384-385.

Animesh, G. and Ghosh, B. 2011. Foliar application of growth regulators and micronutrients on retention, yield and quality of fruit in mango cv. Amrapali. Global conference on Augumenting production and utilization of Mango: Biotic and Abiotic Stresses, Lucknow. 21-24 ${ }^{\text {th }}$ June 2011, p. 77 (abstract).

Anonymous, 2017-18. National Horticulture Board Database. Ministry of Agriculture and Farmers Welfare, Government of India, Gurgoan, India. $38,146$.

Balamohan, T., Gopu, B., 2014. Canopy management in mango (Mangifera indica L.) cv. Alphonso under high density planting system. National conference on value chain management in mango. Srinivasapura, Kolar (Dist), Karnataka. 29-37.

Balasubramanyan, S., Auxicilla, J. and Anbu, S. 2006. Studies on planting cum high density planting in mango cv. Nellum. National Seminar on ATSH, Annamalai Uiversity, Annamalai, March 20-21, 2006, 53(abstract).

Balasubramanyan, S., Saraswathy, S., Parthiban, S., Sankaranarayanan, R., Revathy, N., Rajamanickam, C., 2009. Effect of planting densities on mango (Mangifera indica L.). In: National Seminar on "Production, Post-harvest
Technology and Marketing of Mango" held on 23-25 September 2009 at Horticultural College and Research Institute, Periyakulam (TNAU). 79-81.

Bamini, T., Parthiban, S and Manivanam, M.I. 2009. Effect of pruning and paclobutrazol on yield and quality of mango (Mangiftra indica var. Neelam). Asia Science, 4(1\&2):65-68

Bhagwan, A., Vanajalatha, K, Sarkar, S.K., Girwani, A., and Misra, A.K. 2013. Standardization of dose and time of soil application of cultar on flowering and yield in mango cv. Banganapalli. Journal of Eco-friendly Agriculture, 8(1): 39-43.

Black RE, Allen AH, Bhutta ZA, Caulfield LE, Onis M, Ezzati M, Mathers C \& Rivera J (2008) Maternal and child undernutrition: global and regional exposures and health consequences. The Lancet 371: 243-260.

Blaikie, S.J., Kulkarni, V.J. and Muller,W.J. (2004). Effects of morphactin and paclobutrazol flowering treatments on shoot and root phenology in mango cv. Kensington Pride. Sci. Hortic., 101: 51 $-68$.

Chaudhari, A.U., Krishna, B., Soman, P., Balasubrahmaniam, V.R., 2019. Development of a package for intensive cultivation of mango using Ultra-HighDensity Planting (UHDP), drip and fertigation technologies for higher productivity. International Journal of Agriculture Sciences. 11(23), 9280 9284.

Chaudhuri, D., Patel, N.L. Patel, N.B. Tandel, Y.N. and Gurjar, T. 2014. Effect of foliar spray of growth retardants on flowering, fruiting and yield of mango. (Mangifera indica L.) cv. Kesar. Trends in Bioscience, 7(22): 3765-3767.

Chusri, O, Kozai, N., Ogata, T., Higuchi, H. and Yonemoto, Y. 2008. Application of paclobutrazol for flowering and fruit 
production of 'Irwin' mango (Mangifera indica L.) in Okinawa. Tropical Agriculture and Development, 52(3): 69-73.

Dalal, S.R., Gonge, V.S., Jadhao, B.J. and Jagdande, N.D. 2005. Effect of chemicals on flowering and fruit yield of mango var. Pairy International Journal of Agricultural Sciences, 1(1): 24-25.

Davenport, T.L., 2003. Management of flowering in tropical and subtropical fruit tree species. Hort. Sci. 38, 13311335.

Davenport, T.L., 2006. Pruning strategies to maximize tropical mango production from the time of planting to restoration of old orchards. Hort Science. 41, 544548.

Devender, D.S.F., van Teery, L.A., Polenta, G.A. and Koresten, L. 2012. Combination of 1-methyle cyclopropane treatment and controlled atmosphere storage retains overall fruit quality and bioactive compounds in mango. Journal of the Science of Food and Agriculture, 92(4): 821-830.

Gaikwad, S.P., Chalak, S.U., Kamble, A.B., 2017. Effect of Spacing on Growth, Yield and Quality of Mango. J Krishi Vigyan. 5(2), 50-53.

Galan Sauco, V. 2013. World wide Mango production and Market: Current, Situation and Future Prospects. Acta Horticulture, 992:37-48.

Gopu, B., Balamohan, T.N., Soman, P., Jeyakumar, P., 2014. Canopy management in mango (Mangiferaindica L.) cv. Alphonso with reference to flowering, yield and quality characters under ultra-highdensity planting. Journal of Applied Horticulture. 16(1), 50-53.

Gopu, B., Balamohan, T.N.20015. Crop regulation using chemicals for flowering and fruit set in mango
(Mangifera indica L.) cv. Alphonso under ultra high density planting. Trends in Biosciences, 2: 436 -441.

Hoda, M.N., Singh, S. and Singh, J. 2001. Effect of cultar on flowering, fruiting and fruit quality of mango cv. Langra. Indian Journal of Horticulture, 53(3): 224-227.

Hojo, E.T.D., Abren, C.M.P., de Correa, A.D. and Boas, E.V. de B.V. 2006. Performance of 'Palmer mangoes treated with methyl cyclopropane and stored under refrigeration Regist Brasileiva de Amazen amento, 31(2):181-186.

Husen, S, Kuswanto, Ansari, S. and Basuki, N. 2012. Induction of flowering and yield of mango hybrids using paclobutrazol. Journal of Agriculture and Food Technology, 2(9): 153-158.

Jahangeer, A.B., Akbar, P., Ishfaq Vijai, K., 2011. Rejuvenation of old and senile orchards: a review. Annals of Horticulture. 4 (1), 37 - 44.

Jain, S.K. and Mukherjee, S. 2001. Postharvest application of $\mathrm{GA}_{3}$ to delay ripening in mango (Mangifera indica L.) cv. Langra. Journal of Ecophysiology, 4(1/2):27-30.

Karuna, K. Mankar, A. 2008. Effect of urea, pacloabutrazol and bio-regulators on vegetative growth and productivity of Langra mango. Orissa Journal of Horticulture, 36(2):88-92.

Karuna, K., Manka, A. and Singh, J. (2007). Effect of urea and growth substances on yield and quality of mango cv. Langra. Orissa journal of Horticulture, 35(1):67-70.

Karuna, K., Mankar, A. and Singh, J. 2005. Effect of urea and growth substances on yield, physio - chemical characteristics of mango. Horticulture Journal, 18(3): 131-133.

Kaushik, D., Pallab, D., 2018. Effects of Mulching on Soil Properties and Post 
Harvest Quality of Mango Cv. Himsagar Grown in New Alluvial Zone of West Bengal. Int. J. Agric. Env. and Biotech. 11(2), 259-264.

Kumar K, Adak T \& Singh VK (2015) Status and distribution of micronutrients in mango orchards under subtropical region of Uttar Pradesh, India. Journal of Agricultural Physics 15(2): 127-139.

Kumar, A., Malik, S., Chaudhary, P and Kumar, N. 2017. Studies on the growth and flowering of different mango (Mangifera indica L.) cultivars under Western Uttar Pradesh conditions. Journal of Pharmacognosy and Phytochemistry. 439-442.

Kumar, N., 2013. Drip-fertigation to increase the productivity of mango cv. Alphonso raised under Ultra-High Density Planting (UHDP) system. Paper presented at the XXII International Plant Nutrition Colloquium meeting (IPNC) held at Istanbul, Turkey from 19th to 22nd August 2013.

Kumar, N., 2019. High Density Planting in Mango- Prospects and Problems. Advanced Agricultural Research \& Technology Journal. 3(1).

Majumder, P.K., Sharma, D. K and Sanyal, D. 2001. Mango. Bose, T. K., Mitra, S. K and Sanyal, D. Tropical and Subtropical. Partha Sankar Basu, Naya Udyog, Calcutta - 2.

Maloba, S., Ambuko, J., Hutchinson, M., Owino, W., 2017. Off-Season flower induction in mango fruits using ethephon and potassium nitrate. J. Agril., Sci. 9(9), 158-167.

Muthaia, Edward Raja. 2009. Is Mango genetically prone to Zinc deficiency: An investigation in Peninsular India. UC Davis. The Proceedings of the International Plant Nutrition Colloquium XVI https://escholarship.org/uc/item/9db6g9 $3 \mathrm{v}$.
Nath, V., Das, B. Rai, M., 2007. Standardization of high-density planting in mango (Mangifera indica) under sub-humid Alisols of Eastern India. Indian J Agrli Sci. 77, 3-7.

Oosthuyse, S.A., 2009. Management of a 'Tommy Atkins', ultra-high-density orchard and recognized benefits associated with small tree mango orchards. Acta Hort. 820, 335-338.

Panwar, R., Singh, S.K., Singh, C.P., Singh, P.K., 2007. Mango fruit yield and quality improvement through fertigation along with mulch. Indian J. Agric. Sci. 77 (10), 680-684.

Patil, K.R., Burondkar, M.M., Bhave, S.G., Nigade, P.M., 2013. Post-Harvest Chemical induction of vegetative growth and its physiological behavior in relation to regulation of flowering in 'Alphonso' mango (Mangifera indica L.) Proc. IXth Intl. Mango Symposium. Acta Hort. 992, 193-200.

Ram, S., Singh, C.P., Shukla P., 2001. Effect of different planting densities on growth and yield of mango. Indian J. Hort. 58, 191- 195.

Rawat, P.L., Yogesh, P.R., 2018. Studies on the effect of pruning on growth and yield of old and senile mango varieties. International J. of Chem Studies. 6(4), 2869-2873.

Shaban, A.E.A., 2009. Effects of summer pruning and GA3 spraying on inducing flowering and fruiting of Zebda mango trees. World J. Agri. sci. 5(3), 337-344.

Sharma, R.R., Singh, R., Singh, D.S., 2006. Influence of pruning intensity on light penetration and leaf physiology in highdensity orchards of mango trees. Fruits. 61, 117-123.

Singh MV (2001) Evaluation of micronutrient status of difference agroecological zones of India. Fertiliser News 46(2): 25-42.

Srinivas, K., 2006. Fertigation studies in high 
density mango. In: National Symp. on Improving Input Efficiency in Horticulture. IIHR, Bangalore. 150.

Swaroop, M., Singh, C.P.S., Shukla, P., 2010. Effect of pruning on growth, flowering and fruiting in mango. Indian J. Hort. 58, 303-308.

Upreti, K.K., Shivuprasad, S.R., Reddy, Y.T.N., Rajeswara, A.N., 2014. Paclobutrazol induced changes in carbohydrates and some associated enzymes during floral initiation in mango (Mangifera indica L.) cv. Totapuri. Indian J. Pl. Physiol. 19, 317 323.

Usha Rani, K., 2018. Advances in Crop Regulation in Mango (Mangifera indica L.). Int.J.Curr.Microbiol.App.Sci. 7(9), $35-42$.

Verma*, Tarun Adak And Kailash Kumar. 2018. An Expert System for Identification of Nutrients Deficiency/ Disorder and Their Management Advisories in Mango (Mangifera indica L.). Journal of Agricultural Physics, 18 (1): $74-81$.

Vijay Krishna, G., Bhagwan, A., Raj Kumar,
M., Siva Shankar, A., 2016. Effect of flower enhancing plant growth regulators and fruit set improving chemicals on flowering and fruit set of mango (Mangifera indica L.) $\mathrm{cv}$. Banganpalli. Int. J. Sci. Nature. 7(1), 81-88.

Vinod, K., Wali, P.B., Akash, S., Ajitpa, S., Manish, B., Nirjeet, K., 2017.In: Book. Rejuvination of unproductive old mango orchards. 32.

Waghmare, G.M., Joshi, G.D., 2008. Response of mango (Mangifera indica. L) to light pruning for vegetative and flowering flushes. Indian J. Agri. Sci. 78, 651-654.

Yeshitela, T., Robbertse, P.J., Stassen, P.J.C., 2003. The impact of panicle and shoot pruning on inflorescence and yield related developments in some mango cultivars. J. Appl. Hort. 5(2), 69-75.

Yeshitela,T., Robbertse, P.J. and Stassen, P.J.C.2005. Effects of pruning on flowering, yield and fruit quality in mango (Mangifera indica). Aust,J. Exp.AGric., 45, 1325 - 1330.

\section{How to cite this article:}

Parthiban, S., V. P. Santhi, M. S. Snehapriya, K. Indumathi and Masilamani, P. 2020. Recent Advances in Enhancing the Productivity of Mango (Mangifera indica L.) through Hi-tech Practices. Int.J.Curr.Microbiol.App.Sci. 9(08): 1850-1864. doi: https://doi.org/10.20546/ijcmas.2020.908.212 